\title{
Article \\ Globalization, Cultural Heritage Management and the Sustainable Development Goals in Sub-Saharan Africa: The Case of Nigeria
}

\author{
Caleb A. Folorunso
}

check for

updates

Citation: Folorunso, C.A.

Globalization, Cultural Heritage

Management and the Sustainable

Development Goals in Sub-Saharan

Africa: The Case of Nigeria. Heritage 2021, 4, 1703-1715. https://doi.org/ 10.3390/heritage4030094

Academic Editors: Claire Smith, Lilia Lucia Lizama, Israel Herrera and Alok Kumar Kanungo

Received: 16 June 2021

Accepted: 31 July 2021

Published: 11 August 2021

Publisher's Note: MDPI stays neutral with regard to jurisdictional claims in published maps and institutional affiliations.

Copyright: (C) 2021 by the author. Licensee MDPI, Basel, Switzerland. This article is an open access article distributed under the terms and conditions of the Creative Commons Attribution (CC BY) license (https:/ / creativecommons.org/licenses/by/ $4.0 /)$.
Department of Archaeology and Anthropology, University of Ibadan, Ibadan 200284, Nigeria; ca.folorunso@mail.ui.edu.ng

\begin{abstract}
This paper addresses the impacts of globalization on cultural heritage conservation in sub-Saharan Africa. The homogenization and commodification of Indigenous cultures as a result of globalization and it's impacts on the devaluation of heritage sites and cultural properties is discussed within a Nigerian context. Additionally, the ongoing global demand for African art objects continues to fuel the looting and destruction of archaeological and historical sites, negatively impacting the wellbeing of local communities and their relationships to their cultural heritage. Global organizations and institutions such as UNESCO, the World Bank, and other institutions have been important stakeholders in the protection of cultural heritage worldwide. This paper assesses the efficacy of the policies and interventions implemented by these organizations and institutions within Africa and makes suggestions on how to advance the protection of African cultural heritage within the Sustainable Development Goals (SDGs). Furthermore, cultural heritage conservation is explored as a core element of community well-being and a tool with which African nations may achieve sustainable economic development.
\end{abstract}

Keywords: globalization; West Africa; trans-Saharan; trans-Atlantic; colonial; heritage; SDGs

\section{Introduction}

The Covid 19 pandemic that broke out in China in late 2019 and spread rapidly to other parts of the globe in the first quarter of 2020 was a demonstration of the meaning and impact of globalization. The current World's experience is in tandem with the definition of Thomas Larsson, ref. [1] that globalization "is the process of world shrinkage, of distances getting shorter, things moving closer". Globalization is the compressing of the world and intensifying the consciousness of the world as a whole [2]. The intensification of worldwide social relations has brought distant localities closer in such a way that local happenings are shaped by events occurring in disparate locations [3]. Globalization could therefore be viewed as the speedup of movements and exchanges of human beings, goods and services, capital, technologies or cultural practices all over the world. Viewed through the lenses of the economy, culture and politics, globalization is essentially an economic process of interaction and integration that is associated with social and cultural aspects which have implications for international politics [4].

While globalization in its current form is a relatively modern phenomenon, the genesis of globalization could theoretically be traced to the prehistoric periods when early humans spread and colonized new territories and thereby started to shrink the world, and this has been amplified in historic and modern times resulting to indelible consequences on the world's cultural landscapes. For Sub-Saharan Africa, the trans-Saharan trade networks linked parts of the region to the Arab world centuries earlier than the trade links and cultural exchanges that characterized the period of the rise of maritime European (Portuguese, Spanish, Dutch and British) empires in the 15th and the 17th centuries, which marked the beginning of modern globalization. The early phase is distinguished from modern 
globalization on the basis of expansionism, the method of managing global trade, and the level of information exchange. Economic globalization had birthed cultural globalization which could be described as the transmission of ideas, meanings, and values around the world. Cultural globalization involves the formation of shared norms and knowledge which define the individual and collective cultural identities. Different populations and cultures are increasingly brought into interconnectedness [5].

Critics of globalization had, however, argued that globalization could become a threat to cultural diversity and might lead to cultural domination by the world's economic powers and cause great harm to local cultures [6]. With the acceleration and intensification in global flows of capital, labor and information, local cultures are being increasingly homogenized. Though globalization has, in some ways, encouraged the integration of societies and provided new opportunities to millions of people, it has also contributed to the commodification of cultures and loss of marginalized identities in the name of progress and modernization [7].

\section{West Africa in the Global Theatre}

The trans-Saharan trade routes were the earliest networks of contact between the interior of West Africa and North Africa which could be treated as ancient manifestations of globalization in West Africa. The ancient trade networks left indelible tangible and intangible heritage dating back to the 12th century A.D. For example, the trading centres of Ouadane, Chinguetti, Tichitt and Oualata in Mauretania developed in the 11th and 12th centuries on the southern limits of the Saho-Sahelian desert to serve the caravans crossing the Sahara. They were centers of trading and Islamic culture and have preserved an urban fabric that evolved between the 12th and 16th centuries [8]. Similarly, Djenné, Timbuktu and Gao in Mali developed in the 15th and 16th centuries. Djenné is renowned for its intensive and remarkable use of earth for constructions and have nearly 2000 traditional houses built on hillocks that have survived. Timbuktu was home to the prestigious Koranic Sankore School and had three great mosques that are exceptional examples of earthen architecture continuously being restored. Gao is home to the dramatic 17 metres pyramidal structure of the Tomb of Askia built in 1494. Gao was the capital of the Songhai Empire which flourished in the 15th and 16th centuries [9]. Relics of the trans-Saharan trade that are heritage monuments are also located in Agadez, in Niger, and they date to the same period of the 15th and 16th centuries. These include numerous earthen dwellings and a well-preserved group of palatial and religious buildings, and a 27 metres high minaret made entirely of mud brick [9] (See Figure 1).

The European exploration to West Africa in the 15th century effectively linked West Africa to the Atlantic world. In the search for a sea route to India by European explorers, the Gambia River became one of the first cultural exchange zones between Africa and Europe. In 1456 the Portuguese bought the Kunta Kinteh Island in the Gambia River where it joins the Atlantic Ocean to build a fort. Between 1482 and 1786 the Portuguese established fortified trading posts which now constitute a unique collective monument along the coast of Ghana between Keta in the east and Beyin in the west. Gorée, an island of 28 hectares lying off the coast of Senegal, the Republic of Cape Verde, a nation of islands about $644 \mathrm{~km}$ west of Senegal in the Atlantic Ocean and the Bunce Island Slave Castle, located about $32 \mathrm{~km}$ upriver from Freetown are all testimonies to the heritage of the trans-Atlantic trade on the West African coast [9].

The trans-Saharan era and the trans-Atlantic heritage sites are sadly and mostly the prominent cultural properties in West Africa that enjoy international cooperation for conservation through the UNESCO World Heritage Convention of 1972 which is a hallmark of modern globalization. 


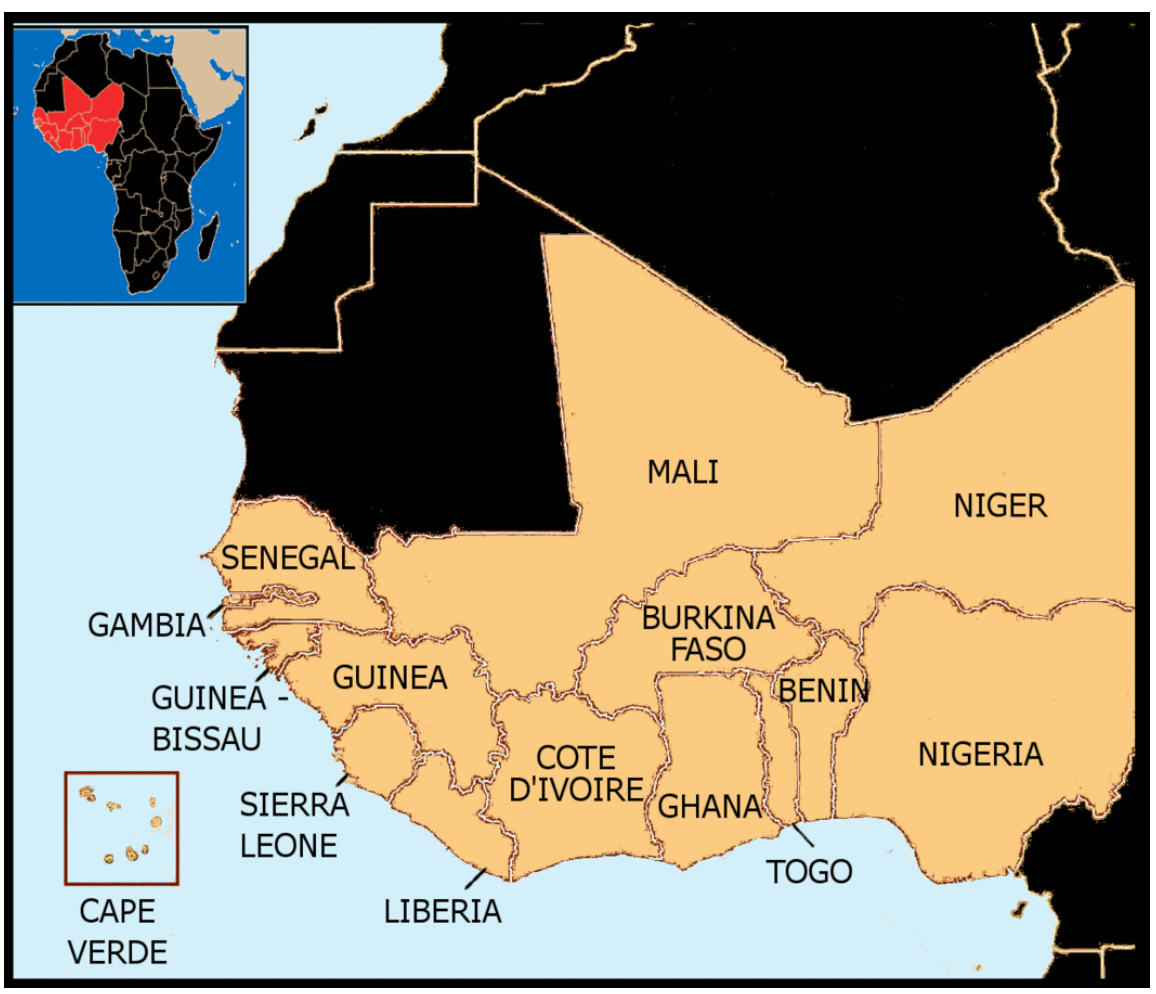

Figure 1. Map of West Africa [10]. Attribution: Mondo Magic, Public domain, via Wikimedia Commons.

\section{Trans-Atlantic Heritage in Nigeria}

The coastline of Nigeria was of key importance for pre-colonial European trade and colonial interventions. The entire town of Badagry on the southwest coast is a living historical museum, with important landmarks that include the Gberefu ancient beach port reputed for trade in salt before its strategic involvement in the transatlantic slave trade [11]. No fort was built in Badagry, only makeshift Barracoon cells were used to keep slaves. A private museum (the House of Chief William Abbas) was the last standing Brazilian Barracoon in Badagry. The Vlekete slave market at the centre of the town, established in 1502 , functioned until 1808 as the largest slave market in West Africa. Badagry was noted for the Christian missionary activities in the mid-19th century, with the mission constructing the first multi-story building in Nigeria in 1845. The District Officer's Residence was erected in 1870 and now houses the Badagry Black Heritage Museum. There was also the cemetery where the first Christian missionaries in Nigeria were buried [12]. In 1876, Topo Island in the Badagry area was acquired by the Catholic Mission to establish a coconut plantation. Sites remaining on the Island include the Chapel, Father's House, Convent and Teacher Training College, and cemetery where several missionaries were buried. However, the coconut plantation is the only thing that seems to have survived the test of time [13].

Calabar on the southeast coast was a historic seaport city and a former slave trading post, strategically located near the Cameroon border. It was known in the 16th century for palm oil trade before it became one of the major slave ports. It was an important post for international trade and colonial administration, it hosted the earliest military barracks and the first Presbyterian Church in Nigeria in 1846. The city of Lagos was and is still host to a number of precolonial and colonial buildings and landscapes which were the products of influence from the Atlantic world. These included domestic architectural forms introduced by returnee liberated slaves from Brazil who were masons. Other cities and centres across Nigeria were dotted with colonial historic properties particularly Zungeru the capital of the British protectorate of Northern Nigeria from 1902 to 1916, and there had been no conservation policies or plans for all these historic structures which were either in a state of disuse or had given way to urban renewal. Only two ethnographic properties in Nigeria, the Osun Osogbo Groove in the southwest and the Sukur Cultural Landscape 
in the northeast, were on the UNESCO world heritage list. Heritage properties declared national monuments were not immune to destruction as a Brazilian style house built in 1855 on Lagos Island, declared a national monument in 1956, was demolished by land speculators in 2016 [14].

\section{Colonial Period and the Management of Cultural Resources}

As globalization in the past created its own heritage in Africa, so too did it cause destruction to cultural heritage. The exposure of European traders, missionaries, travelers, anthropologists, and colonial officers to African cultural materials created the first set of problems for the conservation of heritage properties. There had been revelations that Christian missionaries, while converting the locals to Christianity, demanded they surrender objects (artefacts) of their worship. Many such objects were destroyed while some found their way to Europe and are today housed in museums and private collections. S.T. Ola Akande [15], a Nigerian Baptist Church clergy member, vividly described the role of Christian missionaries in the assault against African cultural properties as cited below:

"Many of the worshippers of this African traditional heathenistic religion later accepted the Gospel message and gave their lives to Christ. They then submitted their idols and other objects of worship to the missionary preachers and their African assistants. Many of these idols as well as other objects of worship submitted to the missionaries are preserved in the libraries of the seminaries and the headquarter offices of the missionary societies that sent missionaries to Africa from Europe, North America etc." [15] (pp. 5-6).

"Several persons have borne testimony to the pride and joy with which many new converts turned over to the church the objects of their heathen worship, some of which were idols, beads, rings, amulets, colourful clothes and plates for sacrificial meals. Many of these were burnt in the open by pastors and church elders to signify the fire of hell that would destroy all things which give offence. This writer has been a witness to such burning ceremonies which symbolized that converts were breaking with the past" [15] (p. 79).

"... . . many converts into Christianity are still bound inextricably to the old practices of their pre-regenerate lives, even in spite of the fact that their former paraphernalia of pagan worship were destroyed in huge fires.

Perhaps I should say that the black rings, the amulets, the magic belts, the idols, the beads, the plates etc., which were the emblems of paganism, should have been preserved rather than destroyed by the church leaders and missionaries because they would today have become very useful for a greater understanding of the traditional African religion of our forebears before the arrival of christianization and evangelization. Perhaps other emblems of pagan worship which were hidden away in Europe and the USA would one day come to the surface and be returned to Africa" [15] (p. 80).

It is apparent from the above quotations that S.T. Ola Akande having noted, witnessed, and/or participated in the destruction of African heritage properties by church leaders and missionaries had come to realize their importance. Akande expressed his regrets and desire for the repatriation of artefacts taken to Europe and America.

The British administrators and military officers sent to Africa to lay the foundation of the emerging colonial administration $a b$ initio had the mind of looting African cultural properties. Resistance to the activities of expanding European influence and interest in Africa presented an excuse for European forces to invade, destroy and loot African communities. The Benin punitive expedition of the British forces in 1897 was a classic example of wanton destruction and looting of cultural properties. The leader of the expedition had estimated that sufficient ivory would be found in the King's house to pay for the expenses of invading Benin. Much of the carved woodworks of the Oba's palace were lost to fire, although the bronze sculptures did survive. The British looted the kingdom taking large quantities of sculpture and regalia including works in wood, ivory and brass dating from the 16th century. The objects were auctioned in Europe and are now domiciled in museums across Europe and America, specifically in London, Chicago, Vienna, Paris and Berlin [16]. Annalisa Bolin [17] provided the transcription of the question posed by the 
villain Eric Killmonger, played by Michael B. Jordan in the film "Black Panther" to a British museum curator eyeing African artwork, "How do you think your ancestors got these? You think they paid a fair price? Or did they take it, like they took everything else?" The Asante Kingdom in the Gold Coast (Ghana) had earlier suffered a similar invasion of Kumasi by British forces in 1896, an invasion that was solely targeted at looting cultural properties [18].

The European penetration into Africa also witnessed the interventions of Western Anthropologists. Leo Frobenius, a German anthropologist visited Ife in November 1910 to find out about the sacred city of Yoruba. Frobenius dug up several buried terracotta figurines without following known scientific excavation or recording techniques and instructed local community members to dig in search of artefacts at spots where legend indicated ancestral gods had disappeared into the ground [19]. The activities of Frobenius in Ife would be better described as treasure hunting in the name of colonial enterprise than archaeological enquiry.

The activities of colonial administrations in mineral resources exploration, construction of roads, water reservoirs and housing in Nigeria, exposed archaeological heritage to the danger of destruction and looting. The first piece of the Nok terracotta figurines was found in 1928 at a tin mine close to Nok village near the Jos plateau; Following the initial discovery, subsequent fragments of the figurines were found. Unfortunately, the resulting global attention positioned the figurines as primary targets for looting and international trafficking [20-22]. The international antiquity market had debilitating effects on tangible cultural properties in Nigeria as looting had extended to objects in museum collections, shrines, palaces and other cultural places such as sacred groves and forests.

On the positive side, the colonial administration laid the foundation for formal cultural heritage management. In 1938, there were accidental finds of archaeological materials at Ife in Western Nigeria where workmen found some brass heads while digging the foundation of a house in the Wunmonije Compound, a short distance from the palace, as well as at Igbo Ukwu in Eastern Nigeria where bronze objects were found by a man was digging beside his home. Similar finds also occurred at Benin in mid-Western Nigeria to which the colonial administration responded with the establishment of the Nigerian Department of Antiquities and the appointment of foreign professional archaeologists in 1943 to take charge of the management of the archaeological resources [23].

At independence in 1960, Nigeria still depended on foreign archaeologists to conduct research and undertake rescue excavations. The works by Graham Connah in Benin in the 1960s, particularly at the Museum site, were rescue in nature [24]. The construction of the Kainji Dam was preceded in 1962-1963 by an archaeological survey of the area to be flooded, though the exercise was later bungled [25]. Thus, interest in the protection of archaeological resources threatened by land modification was fast waning after independence, such that salvage/rescue archaeology was not considered in the significant construction works involved in urban renewal, the development of new facilities, and establishment of a new capital city in Nigeria [26]. The post-Independence period has therefore witnessed mining and construction projects resulting in unmitigated destruction and disturbance of numerous cultural sites.

\section{Impact of Global Financial Institutions}

The growth of globalization in the contemporary world has resulted in the increased destruction of cultural heritage properties over the last two decades. With the ease by which governments at state and the federal levels are able to access global funds for infrastructural developments, the destruction of cultural heritage properties has been exacerbated. It had long been recognized that developing nations such as Nigeria could not afford to build cultural resources management into the planning of development projects [14]. It is therefore incumbent on global financial institutions funding projects in economicallydisadvantaged nations to consider the protection of cultural heritage properties in the planning of projects. The World Bank had a policy requiring environmental assessment (EA) to ensure that projects were environmentally sustainable. The Bank particularly 
favored preventive over mitigatory or compensatory measures. The World Bank policy addressed physical cultural resources, which include movable and immovable objects, sites, structures, groups of structures, natural features and landscapes that had archaeological, paleontological, historical, architectural, religious, aesthetic, and other cultural significance. Physical cultural resources were considered as assets for economic and social development, and as integral parts of a people's cultural identity and practices; the Bank sought to assist countries in avoiding or mitigating adverse impacts on such properties [27,28].

Many projects in Nigeria had been funded by the World Bank but it had been neither practical nor possible for cultural heritage practitioners or interest parties to conduct independent auditing and verification in compliance with the policies of the World Bank on physical cultural resources. There had always been the problem of the lack of a competent national agency that would ensure compliance with World Bank policy by multinational companies operating within Nigeria. The agency entrusted with the management of physical cultural resources in Nigeria, the National Commission for Museums and Monuments (NCMM), like similar agencies in other African nations, was not equipped to pursue such a vision. The mandates of the agencies as enshrined in the relevant but ineffective legislations described elsewhere [28], were not achieved due to a lack of staff and resources. The call for the professionalisation of the agencies had always been an item of the resolutions of the meetings of Archaeological Associations in Africa, particularly the West African Archaeological Association. In the absence of professional agencies that would ensure compliance with the World Bank's policy, it is recommended that global archaeological associations assist in ensuring that global standards of heritage conservation best practice are maintained in developing nations.

The World Archaeological Congress (WAC) is a global association that has had tremendous impact in discussions of cultural resources management in Africa [29]. Since its creation in 1986, the WAC has encouraged the participation and adequate representation of African members at academic meetings and in the decision-making processes of the association. WAC as a global association could serve as a link between regional and national archaeological associations, individual professionals in Africa, and the World Bank's Cultural Resource Management office, to obtain and disseminate information on projects funded by the Bank in Africa. Associations and/or individual professionals could then constitute themselves into focus groups to implement and monitor compliance with the Bank's policy on the management of physical cultural resources by the multinational companies funded by the Bank.

The proliferation of global funds in recent years had complicated the issue of the management of heritage resources in Nigeria. In addition to the World Bank, there are five other major International Financial Institutions (IFI) operating in Africa, they are the African Development Bank, the Asian Development Bank, the Caribbean Development Bank, the European Bank for Reconstruction and Development, and the Inter-American Development Bank. There is no indication that all the aforementioned financial institutions have pursued policies to protect heritage properties in Nigeria. Chinese organisations in particular were very active in the development of infrastructure in Nigeria but were not known to protect heritage properties. To ensure that globalization is desirable for matters of heritage protection, WAC, American Anthropological Association (AAA) and the European Archaeological Association (EAA) should ensure that the IFIs maintain the same standards applicable in the West in issues of cultural resources management for projects funded in Africa.

UNESCO has provided a global platform for the management of cultural resources in Africa through the various conventions. Of particular interest were the Convention on the Means of Prohibiting and Protecting the Illicit Import, Export and Transfer of Ownership of Cultural Property, Paris 1970 and the Convention concerning the Protection of the World Cultural and Natural Heritage, Paris 1972. The 1970 Convention is a legal framework to protect movable cultural properties against antiquity trafficking, but the Convention has not had impact in Nigeria where archaeological sites and places housing 
cultural objects continue to be looted because of the absence of strong national legislation for the protection of heritage properties. The 1972 Convention provides the opportunity for nations to nominate physical heritage properties to be considered for inclusion on the World Heritage List for which successful nominations would enjoy a level of funding for preservation purpose [30]. At present, Nigeria has only two properties on the World Heritage List both of which are ethnographic properties thereby missing out on global funding for the preservation of archaeological and historical properties. The failure of Nigeria and many West African countries to adequately benefit from global funding for preservation of heritage properties is the direct result of the lack of professionalism of the agency charged with the management of the nation's heritage resources.

\section{The Concept of Sustainable Development}

There remains debate internationally over the exact meaning and extent of sustainable development [31]. The World Commission on Environment and Development defines it as "development that meets the needs of present generation without compromising the abilities of the future generations to meet their own needs" [32] (p. 74). The first use of the concept of sustainable development can be traced to the early 18th century when it denoted the protection and preservation of forests and wood resources. When the concept entered public discourse in the second half of the 20th century, it was championed by the environmentalist social movement in response to the large-scale environmental exploitation and destruction associated with rapid economic growth [33]. Sustainability would mean achieving a state of environmental, economic, and social improvement that could be reasonably maintained indefinitely. The protection and enhancement of natural resources are bound in an interdependent relationship to economic and social dimensions of development such that the present generation would not jeopardize the chances of future generations [34]. The concept of sustainable development, therefore, presupposes an economic development that would not slow down, which would be self-perpetuating and ecologically sustainable [32].

The environment-centric view of sustainability by its near-exclusive focus on the environment has inadvertently placed environmental issues in direct conflict with economic and social developments which are primary concerns for developing economies, and certain international environmental legislations are considered to be an impediment to the socioeconomic advancement of developing economies [33]. It is also noted that the concerns of sustainable development had originally been on the use of natural resources by the present generation for economic and social benefits in a manner that would not impact on the abilities of future generations to enjoy the same benefits. This aim, however, failed to address the impacts of the present generation on the inherited environment of previous generations.

It has been observed that the concept of sustainable development in recent decades, evolved with impetus from the general systems theory of the 1960s which created a common ground between the natural and social sciences and expanded the traditional approaches of environmental protection that focused on mitigating the impacts on the natural and, to some extent on social and cultural environment. It had therefore been advanced that, for development to be sustainable, it "must foster protection and rehabilitation of ecological systems, improve economic efficiency and enhance the well-being and cultural diversity of the population" [33] (p. 75).

\section{Sustainable Development Goals (SDGs) and Cultural Heritage}

The Millennium Development Goals (MDGs) for the period 2000 to 2015 were the forerunners of the Sustainable Development Goals (SDGs) that would run for 15 years until 2030 to involve all countries in economic, social, and environmental sustainability. There were eight MDGs and the verdict after 15 years was that "not all the goals have been met, and some regions have benefitted less than others, particularly Sub-Saharan Africa and Southeast Asia" [33] (p. 2). There are diverse views on the place of culture in the 
MDGs and SDGs. One view is that, the SDGs, much like the MDGs, side-lined culture as a dimension of development, and that culture "is absent from the broad aims of sustainable development and the sustainable development goals, and mentioned (a mere five times\} only in the targets, which fall under the goals" [35] (pp. 51-52).

A second view on the place of cultural heritage in the SDGs was that "cultural heritage plays a marginal role" and "is explicitly mentioned only once in the goal 11, that is referred to the cities, in particular to the need of making cities and human settlements inclusive, safe, resilient and sustainable" [34], and that Target 11.4 which called for strengthened "efforts to protect and safeguard the world's cultural and natural heritage" was a weak reference and "deals only with the protection and safeguard of cultural heritage, without any reference to its valorization/regeneration" [34] (p. 3).

Another observer noted that while none of the 17 SDGs focuses exclusively on cultural heritage, "the resulting Agenda includes explicit reference to heritage in SDG 11.4 and indirect reference to other Goals" [36] (p. 1). A more positive view of the SDGs agenda is that it "is simultaneously culminating in several processes, each of which-whether intentionally or not-has been and will be informed by culture and heritage and each of which will undoubtedly have profound consequences on cultural heritage". The contradictions and inconsistencies in resolving the tension between heritage conservation goals and socio-economic development needs and aspirations of local communities have been revealed as unsustainable development practices and uncontrolled urbanization [37] (p. 38).

Yet another opinion was that despite their similarity in some aspects, the SDGs "go well beyond the MDGs in that their formulation and focus are more encompassing, explicitly requiring active participation from wealthy and poor nations alike" shifting focus "from ameliorating the situation in poor and underdeveloped regions and societies toward improving the sustainability of global economic and social development, while concurrently protecting the environment everywhere" The understanding is that nations would have "different visions, capacities, and approaches to collectively strive toward achieving the 17 UN SDGs" [33] (p. 2).

It has been posited that many discussions on the role of cultural heritage in sustainable development had been presented only on a theoretical level which requires the production of empirical evidence demonstrating the benefits of cultural landscape conservation to improved economic, social, and environmental productivity; that is, it should be demonstrated that cultural heritage conservation/valorization is an investment and not a cost. Indeed, there are at present few studies "about the indicators that are able to support the relationship between cultural heritage conservation/regeneration and sustainable development" [34] (p. 1). This view tends to emphasize the economic/commercial value of heritage through a material cost and benefit approach of development that ignores the symbiotic relationship between culture and economic growth that cannot be evaluated on the basis of material transaction. The approach reduces culture to a commodity and any investment in the culture sector that would not yield economic returns is considered unsustainable thus situating the preservation of cultural heritage as a barrier to economic development.

Significant to this discussion is the view that cultural heritage is a luxury in emerging and developing countries where economic development is an urgent necessity. This view posits economic growth and heritage conservation as opposing goals not as interconnected elements of well-being. There is also the misconception that "heritage conservation should narrowly focus on conservation and restoration and any mention of development would open doors for rampant commercial development." This point of view emphasizes commercial development motivated by profit margins and ignores inclusive sustainable development [37] (p. 45).

\section{Cultural Heritage and the SDGs}

Despite the non-explicit inclusion of cultural heritage in the SDGs, the implicit importance of cultural heritage for the attainment of the goals has been highlighted. UNESCO 
has called upon state parties to the World Heritage Convention to "ensure an appropriate and equitable balance between conservation, sustainability and development, so that World Heritage properties can be protected through appropriate activities contributing to the social and economic development and the quality of life of our communities." It is opined that the identification, protection, conservation, presentation, and transmission of irreplaceable cultural and natural heritage properties to present and future generations contribute "significantly to sustainable development and the wellbeing of people." The World Heritage sites if properly managed, are believed to possess "great potentials for inclusive local economic development, sustainability and strengthening social resilience" through sustainable community-based forms of tourism development [38] (pp. 1,9).

It has been highlighted that "well-being and development are intimately bound up with other people and the natural world", therefore development ought to be the basis for the enablement, expansion, and promotion of "harmonious relationships between people and the natural world". The contribution of cultures to sustainable development should not merely mean support from traditional knowledge and practices in the pursuit and achievement of sustainable goals, but that Indigenous values are employed as the foundations for sustainable development". Here it is suggested that well-being and poverty be understood in terms of relationships; Poverty should not only be assessed by a lack of material wealth but also the content and quality of relationships with other people, and connections to, and expressions of, culture [35] (p. 52).

Culture plays a role in the promotion and implementation of sustainable consumption and production patterns, and it is a key element in the humanization of cities and human settlement. It has been suggested that engagement in cultural activities significantly increases overall life satisfaction... Indeed, "Wellbeing is not related only to the economic wealth, but also to the condition able to ensure social cohesion" [34] (p. 22). The relationship between cultural heritage and sustainable development is better seen in the promotion of social cohesion, inclusion, and equity. The preservation of a community's cultural heritage cannot be complete by the conservation of only artefacts without the promotion of the associated creative activities and living culture. Our approach to conservation and development must embrace planning and management that would resolve the competing goals of conserving heritage and integrating inclusive social and economic development [37].

\section{Globalization, Cultural Heritage and the Sustainable Development Goals}

Cultural globalization, a product of economic globalization, presents a significant threat to sustainable development, notwithstanding the benefits of economic globalization. Globalization processes have increased homogenization and standardization across the world and in doing so resulted in the erasure and commodification of many Indigenous cultures globally. When backed and implemented alongside economic development, cultural heritage conservation can serve as the tool with which communities may mitigate the impacts of cultural globalization alongside sustainable economic growth [32].

It has been observed that global tourism to heritage sites and cities has at times been excessive and insensitive, exacerbating the divide between the importance of heritage to local communities and the demands of global cultures. Additionally, the prospect of cultural heritage as a source of revenue has distorted the value of tangible heritage and its place within local cultures and communities. While it is recognized that tourism could generate social change and revive folk arts, it also commodifies culture by making selective promotion of heritage properties which in turn had hindered inclusive and sustainable development for local communities and marginalized their needs [37] (p. 41). Tourism, if not properly managed, can result in the privatisation of public cultural goods and endangerment of sites through commercialisation and overuse. Tourism would become "more and more commercial entertainment reducing monuments and urban settings to decoration", while the commercialisation of access to heritage resources may lead to an over exploitation and destruction of heritage resources in much the same manner as natural resources continue to be mismanaged [39] (p. 2). It was therefore suggested that actions be 
identified to protect heritage, "to ensure its use, its promotion and enhancement, and its economic, social and cultural value are harnessed to the benefit of local communities and visitors; and to assess the ability of heritage and its inherent values to inspire and to build tomorrow's societies, curbing the negative effects of globalization" [37] (p. 42).

\section{Cultural Heritage and the Sustainable Development Goals in Nigeria}

It has been noted above that Sub-Saharan Africa did not benefit substantially from the MDGs, and several studies have outlined why Nigeria could not meet the targets of the MDGs [40-43]. However, by the assessment of the United Nation Development Programme (UNDP) "Africa has made significant progress on the Millennium Development Goals, including enrolling more children in primary school, particularly girls, increasing the representation of women in national parliament, and reducing child and maternal deaths and the proportion of people infected with HIV" [44]. It was also noted that compared to the MDGs, the SDGs have been formulated with an all-encompassing focus that allows nations at different levels of development to participate in achieving the goals. Nigeria has prioritized and focused on 7 goals out of the 17 SDGs as evident in the 2020 Voluntary National Review (VNR) on Sustainable Development Goals which listed "the issues of poverty (SDG-1), an inclusive economy (SDG-8), health and wellbeing (SDG-3), education (SDG-4), gender equality (SDG-5), the enabling environment of peace and security (SDG-16), and partnerships (SDG-17)" [45] (p. v). The review added that the focus was based on Nigeria's current development priorities and the development objectives of the current administration.

The SDG 11, in which culture was explicitly mentioned was found to be conspicuously missing in the goals prioritized by Nigeria and it was therefore not surprising that culture was mentioned only three times in the 2020 VNR. The first 2 mentions of culture were under poverty (SDG-1), firstly acknowledging in a peripheral manner the role culture could play in sustainable development when it was admitted that Civil Society Organisations (CSOs) and academic institutions "have made intellectual contributions towards overall poverty alleviation strategies, such as scientific evidence or ground-truthing what would work through experience and cultural context" [46] (p. 54). The second mention was in relation to the negative impact of culture on women's empowerment when it was stated inter alia "For women overall, efforts to improve equitable access to agriculture and livelihood resources, including land, agricultural inputs, and education, over the longer term, requires tackling cultural and gender norms that prevent women's empowerment" [46] (p. 55). The third mention of culture was under gender equality (SDG-5) and it sounded negative with the assertion that cultural barriers "reinforce limitations to women's choices, underpinned by customary patriarchal beliefs and social norms which consider women as subordinate to men" [46] (p. 62).

The implementation of the SDGs in Nigeria seems to emphasize sustaining economic development with little attention to cultural heritage. A new book to be published, titled 'Implementing Sustainable Development Goals in Nigeria: Barriers, Prospects and Strategies' [42] had in the table of contents, a section on 'Societal and Cultural Dimensions' but had no chapter devoted to cultural heritage. The SDGs are understood simply as a path towards sustainable improvement to life and well-being for future generations [37]. Well-being is understood in its narrow sense of tackling economic poverty and providing modern healthcare facilities, without understanding poverty from a cultural perspective, which would include ethical, moral, social and spiritual poverty. Wellbeing is conditioned by the ability to meet social and cultural obligations through the participation in traditional performances which presently might be hampered by economic development and modernity, more importantly, economic poverty is viewed differently from one cultural group to another. For example, the Yoruba express the view that the absence of hunger is the absence of poverty. This shows that there cannot be a universal definition of poverty as is the case for many other concepts that are culturally defined. To set a goal to reduce or eradicate poverty would only be achievable when modified to operate within the context 
of individual, cultural definitions of poverty. This is true for the other sustainable development goals, as the processes for achieving the goals, whether intentionally or not, were and would be informed by culture and heritage and would have profound consequences on cultural heritage.

\section{Conclusions: Globalization, Heritage and Sustainable Development}

The consideration for, and the practice of conservation and management of cultural heritage resources are the global best practices in archaeology today. The phrase "global best practice" is in common use in all fields of discourse. It is an acceptance of common standards of doing things to achieve the best results for the common good of all. What is the common good for all in archaeology today? That tangible and intangible archaeological heritage globally receives equal and adequate attention against all forms of negative interferences. These interferences include the destruction and looting of archaeological sites, the trafficking in archaeological objects, and the retention and curating in foreign lands of archaeological materials of other nations without their consent. The global voice in the age of globalization must be clearly and unequivocally in support of safeguarding heritage everywhere, ensuring that existing globally applicable policies and international legal instruments are employed as genuine efforts to achieve their set objectives.

Repatriation and the restitution of looted heritage properties to their original owner countries has gained international attention and support in recent times yet the looting has not stopped. The repatriation and restitution of the Benin cultural objects from Museums and University campuses around the globe to Nigeria is a fast-developing story. The Edo Museum of West African Art (EMOWAA) project is a multilateral global initiative to find common grounds from all sides to achieve the goal of returning the Benin cultural objects to Nigeria and curate them in a museum in Benin. The project was initiated and spearheaded by the Legacy Restoration Trust (LRT) on behalf of the Nigerian government and the people of Edo. It might be too early to start speculating on the extent of the numbers of the objects that would be returned, but the expression of willingness to return artefacts continues to grow.

Globalization presented Africa the opportunities to cease the initiative to demand for the return of cultural objects exported from the continent under different guises using the existing international protocols that would provide funding and technical knowhow for conservation and preservation, however that has not been the case. African governments can no longer afford to delay professionalizing the agencies entrusted with the management of the continent's heritage and show serious commitment to the global agenda for the protection of world heritage. Africa can indeed continue to think local whilst following global trends in the conservation and preservation of cultural heritage resources.

Academics and policy makers for societal development must respect the relationship between cultural heritage and development. As well as recognise the equal role of maintaining well-being economically, environmentally, and culturally. For development to be sustainable the three dimensions of development must be in harmony. At present, many African nations understand sustainable development in the narrow sense of sustained economic growth without adequate consideration for the natural and cultural environments and their impact on the social and cultural wellbeing of the population. Globalization has blocked the vision of many African nations from the repertoire of Indigenous knowledge that could be employed for sustainable development in food production, housing and well-being, and continue to depend on models of development alien to their cultural environments. For development to be sustainable it must be in harmony with local cultural environments and development goals must be malleable to the specific cultural heritage needs of individual communities and contexts.

Funding: This research received no external funding.

Institutional Review Board Statement: Not applicable.

Informed Consent Statement: Not applicable. 


\section{Data Availability Statement: Not applicable.}

Conflicts of Interest: The author declares no conflict of interest.

\section{References}

1. Larsson, T. The Race to the Top: Real Story of Globalization; Cato Institute: Washington, DC, USA, 2001.

2. Robertson, R. Globalization: Social Theory and Global Culture; Reprint. Sd.; Sage: London, UK, 1992.

3. Giddens, A. The Consequences of Modernity; Polity Press: Cambridge, UK, 1990.

4. Mizoguchi, K.; Smith, C. Global Social Archaeologies; Routledge: New York, NY, USA, 2019; pp. 55-62.

5. Jennings, J. Distinguishing past globalizations. In The Routledge Handbook of Archaeology and Globalization; Tamar, H., Ed.; Routledge: New York, NY, USA, 2017; pp. 12-28.

6. Smith, C.; Burke, H.; Ward, G.K. Globalisation and Indigenous peoples: Threat or empowerment? In Indigenous Cultures in an Interconnected World; Smith, C., Ward, G.K., Eds.; UBC Press: Sydney, Australia, 2000; pp. 1-24.

7. Wilk, R.R. Lumping and Splitting: Globalization that reforms the categories of people and things. In Proceedings of the Annual Meeting of the Association for Consumer Research, Austin, TX, USA, 12-16 October 2001.

8. UNESCO. Culture for Sustainable Development. Available online: www.unesco.org/new/en/culture/themes/culture-anddevelopment/the-future-we-want-the-role-of-culture/globalization-and-culture/\#topPage (accessed on 5 December 2020).

9. UNESCO. World Heritage Centre (1992-2020) World Heritage List. Available online: http://whc.unesco.org/ (accessed on 28 July 2021).

10. Wikimedia Map of West Africa. Available online: https://commons.wikimedia.org/wiki/File:Map_of_West_AFrica.gif (accessed on 3 August 2021).

11. Oyediran, W. Port of Badagry, a point of no return: Investigation of maritime slave trade in Nigeria. In Sea Ports and Sea Power: African Maritime Cultural Landscapes; Harris, L., Ed.; Springer Nature: Cham, Switzerland, 2017; pp. 13-25.

12. Environmental Resources Management (n.d) Badagry baseline: APM Terminals-Badagry Port ESIA. unpublished report.

13. Society of African Missions. Topo Island Revisited. 2010. Available online: https://sma.ie/topo-island-revisited/ (accessed on 28 July 2021).

14. Folorunso, C.A. Third world development and the threat to resource conservation: The case of Africa. In Cultural Resource Management in Contemporary Society; McManamon, F.P., Hatton, A., Eds.; Routledge: London, UK, 2000; pp. 31-39.

15. Akande, S.T.O. The Church, the Secret Cults and African Traditions; Agbo Areo Publishers: Ibadan, Nigeria, 2015.

16. Adewumi, A.A. Possessing possession: Who owns Benin artefacts? Inst. Art Law 2015, 20, 229.

17. Bolin, A. What Comes after Art Repatriation. 2020. Available online: https:/ / africasacountry.com/2020/12/after-repatriationwhat-next (accessed on 28 July 2021).

18. Folorunso, C.A. Heritage Resources and Armed Conflicts: An African Perspective. In Cultural Heritage, Ethic, and the Military; Stone, P.G., Ed.; The Boydell Press: Woodbridge, UK, 2011; pp. 158-171.

19. Eyo, E. Odo Ogbe Street and Lafogido: Contrasting archaeological sites in Ile-Ife, Western Nigeria. West Afr. J. Archaeol. 1974, 4, 99-109.

20. Fagg, A. Discovery and early research on the Nok Culture in Nigeria. In Nok-African Sculpture in Archaeological Context; Breunig, P., Ed.; Africa Magna Verlag: Frankfurt, Germany, 2014; pp. 80-90.

21. Jemkur, J. My Adventure with the Nok Culture. In Nok-African Sculpture in Archaeological Context; Breunig, P., Ed.; Africa Magna Verlag: Frankfurt, Germany, 2014; pp. 92-103.

22. Potiskum, U.Y. Making a Living from Gunki. In Nok: African Sculpture in Archaeological Context; Breunig, P., Ed.; Africa Magna Verlag: Frankfurt, Germany, 2014; pp. 74-76.

23. Shaw, T. Archaeology and Nigeria; Ibadan University Press: Ibadan, Nigeria, 1969.

24. Andah, B.W. Thurstan Shaw at Igbo Ukwu: The limits of rescue archaeology. West Afr. J. Archaeol. 1992, $22,33-39$.

25. Shaw, T. Editorial. West Afr. Archaeol. Newsl. 1970, 12, 3-6.

26. Folorunso, C.A. Archaeological sites and heritage in the face of socio-economic development in Nigeria since independence. In L'Archéologie Préventive en Afrique: Enjeux et Perspectives; Naffe, B.O.M., Lanfranchi, R., Schlanger, N., Eds.; Editions Sépia: Saint-Maur-des Fossés, France, 2008; pp. 135-141.

27. World Bank. Safeguard Policies. Available online: http://web.worldbank.org/WBSITE/EXTERNAL/PROJECTS/ EXTPOLICIES/EXTSAFEPOL/0,,menuPK:584441_pagePK:64168427_piPK:64168435_t-heSitePK:584435,00.html (accessed on 2 December 2012).

28. Folorunso, C.A. The Challenges of the Preservation of Archaeological Heritage in West Africa. In Managing Heritage in Africa. Who Cares? Ndoro, W., Chirikure, S., Deacon, J., Eds.; Routledge: London, UK, 2017; pp. 22-33.

29. Smith, C. Global divides and cultural diversity: Challenges for the World Archaeological Congress. Archaeologies 2015, 11, 4-41. [CrossRef]

30. Folorunso, C.A. Ethics of Commercial Archeology: Nigeria. In Encyclopedia of Global Archaeology; Springer International Publishing Ag, Part of Springer Nature: Cham, Switzerland, 2018.

31. Pereira Roders, A.; Van Oers, R. Wedding cultural heritage and sustainable development: Three years after. J. Cult. Herit. Manag. Sustain. Dev. 2014, 4, 2-15. [CrossRef]

32. Gražulevičiūtè, I. Cultural Heritage in the Context of Sustainable Development. Environ. Res. Eng. Manag. 2006, 3, 74-79. 
33. Bergman, Z.; Bergman, M.M.; Fernandes, K.; Grossrieder, D.; Schneider, L. The Contribution of UNESCO Chairs toward Achieving the UN Sustainable Development Goals. Sustainability 2008, 10, 4471. Available online: https://www.mdpi.com/article/10.3390/ heritage4030094/sustainability (accessed on 17 July 2021). [CrossRef]

34. Nocca, F. The Role of Cultural Heritage in Sustainable Development: Multidimensional Indicators as Decision-Making Tool. Sustainability 2017, 9, 1882. Available online: https://www.mdpi.com/article/10.3390/heritage4030094/sustainability (accessed on 17 July 2021). [CrossRef]

35. Watene, K.; Yap, M. Culture and sustainable development: Indigenous contributions. J. Glob. Ethics 2015, 11, 51-55. [CrossRef]

36. Petti, L.; Trillo, C.; Makore, B.N. Cultural Heritage and Sustainable Development Targets: A Possible Harmonisation? Insights from the European Perspective. Sustainability 2020, 12, 926. [CrossRef]

37. Hosagrahar, J.; Soule, J.; Fusco, L.; Potts, G.; Potts, A. Cultural Heritage, the UN Sustainable Development Goals, and the New Urban Agenda. Cult. Herit. SDGs New Urban Agenda BDC 2016, 16, 37-54.

38. In Proceedings of the UNESCO Policy Document for the Integration of a Sustainable Development Perspective into the Processes of the World Heritage Convention as adopted by the General Assembly of States Parties to the World Heritage Convention at its 20th session 2015, Paris, France, 18-20 November 2015.

39. Hassler, U.; Algreen-Ussing, G.; Kohler, N. Cultural Heritage and Sustainable Development. SUIT Position Paper (3). 1 September 2002. Available online: https:/ / adk.elsevierpure.com (accessed on 17 July 2021).

40. Oleribe, O.O.; Taylor-Robinson, S.D. Before Sustainable Development Goals (SDG): Why Nigeria failed to achieve the Millennium Development Goals (MDGs). Pan Afr. Med. J. 2016, 24, 156. [CrossRef] [PubMed]

41. Okoroafor, F.C.; Anuforo, E.E. The Millennium Development Goals (MDGs) and the Problem of Policy Implementation in Nigeria. Int. J. Dev. Manag. Rev. 2012, 7. [CrossRef]

42. Olabode, K.T.; Kayode, A.Y.; Hilary, Z.Y.; Elizabeth, O. Millennium Development Goals (MDGs) in Nigeria: Issues and Problems. Glob. J. Hum. Soc. Sci. C Sociol. Cult. 2014, 14, 42-53.

43. Nigeria Millennium Development Goals End-Point Report. Abridged Version 2015. 20 Pages. Available online: www.mdgs.gov.ng (accessed on 21 July 2021).

44. Sustainable Development Goals/UNDP in Nigeria. Available online: https:/ /www.ng.undp.org (accessed on 21 July 2021).

45. Nigeria: Integration of the SDGs into National Development Planning. A Second Voluntary National Review. June 2020. Report produced by the Government of Federal Republic of Nigeria, The Office of the Senior Special Assistant to the President on SDGs, Abuja, Nigeria, 95 Pages. Available online: https:/ / sustainabledevelopment.un.org (accessed on 20 July 2021).

46. Eghosa, O.; Ekhator, S.M.; Igbinosa, E. Implementing the Sustainable Development Goals in Nigeria: Barriers, Prospects and Strategies; Routledge: London, UK, 2021. 